\title{
Teachers and Humanism
}

\author{
Sophie Devineau \\ Lecturer, Sociology Department, University of Rouen \\ Innovation and Society Research Group (Rouen GRIS) \\ Maurice Halbwachs Centre Dyreso Team at MRSH Caen, France \\ E-mail: sophie.devineau@unicaen.fr
}

\begin{abstract}
Following the large investigation in the labor universe, teachers give a good illustration for "Working to be happy" (Christian Baudelot, Michel Gollac, 2003). But the question is about the reasons: what are the anthropological needs that profession answer through its sociological organization? This article investigates the cohesion of the French teachers of all grades, from pre-school level to university, manifest in the last social movement, and which can be understood as an expression of values and educational background. As one of a number of social strategies, the quest for a certain standard of living may outline the main side of this professional choice: a humanist career resolution for women and men as well.

At the first level, the study provides evidences of the public-private and republican-liberal cleavage, which against all expectations, actually cuts through the male-female divide. So, if we go back to the analyses of Alain Chenu and Nicolas Herpin (2006), we cannot make conclusions on behalf of this professional category, which has shown strong, compact or homogeneous resistance to the restructuring of the order of civic priorities between equality and freedom.

However, the study finds in a second level, that the humanism of the majority of teachers is based on equality of the sexes, security and respect in their work, modest material needs and the importance of time for themselves and their families. This category has found that teaching offers the conditions in which they may uphold values founded on human rights. The cohesion of the French teachers can be understood as an expression against indivudual competition.
\end{abstract}

Keywords: Professions, Teachers, Gender, Social Values, Lifestyle, Choice of profession, Equality, Security, Stability

Establishing the social individual once again places unemployment at centre stage as unemployment and the precarity of employment are among the major concerns of French people (M. Lallement, 2007). Gérard Mauger (2007) has analysed their destructive effect on political awareness among the popular classes. With workers' rights under threat in all areas, the special position occupied by teachers within the professional hierarchy becomes easily identifiable. By comparison, the professional status of teachers has allowed them to preserve the potential for humanism that has elsewhere been jeopardized. Analysis of the teachers' poll demonstrates this rather well (IFOP-Le monde de l'Education, 2007), as it does their interest in international solidarity, with the intermediary categories being most supportive of development aid, (IFOP-AFD, 2006), and also most opposed to the advent of a liberal Europe (IPSOS, 2006).

Overall, as Alain Chenu and Nicolas Herpin (2006) have shown, France's resistance to economic liberalism is based on public opinion that is very desirous of equality and which, contrary to Nordic countries, was won over by this doctrine through a reversal of civic priorities, where liberty would henceforth take precedence over equality. As a result, citizenship as it exists today has little or nothing in common with the universalist heritage of the post-war republican model. Signs of belonging to groups based on gender, generation or ethnic origin are the new building blocks of a mosaic of identities that researchers have called pre-political ("prépolitique"). At any rate, the varying levels of Europeans' adherence to the values of equality and liberty have opened up the stakes of regulation and social cohesion to renewed cost, at a time when the economic history of the Nation-State serves as a reminder of how it recently abandoned its role as protector and of the realignment of the priorities of social justice among Europeans (M. Forsé, 2005). In this sense, members of the teaching profession offer an exceptionally well-placed vantage point on account of their social position at the heart of the middle classes and the importance of their educational function in society. If one concedes that teachers have as much of a duty to transmit values to young people as they do academic knowledge, one must then ask What are the social values 
upon which the humanism of teachers today is founded? Furthermore, the democratisation of schooling implies a framework of civic principles that it may be useful to identify among education professionals. Further still, since according to Jaurès, one teaches what one is as much as what one knows, teachers, who for their pupils represent certain facets of social existence, have yet to be fully understood on a social level.

We know for example that there is no true secession of the middle classes: Edmond Préteceille (2006) has noted that it is above all the upper classes that are the motors of urban segregation. The spatial concentration of teachers with white-collar staff in the civil service, although the literary and scientific professions are not to be ignored - an indication of dissimilitude comparable to that of business managers of 1990 - however, showed the lowest increase between 1990 and 1999. This, of course, relates as much to the material conditions of access to very expensive property in Paris, as it does to the reality of the areas to which teachers are posted by the schools' administration. Nevertheless, the resolutely anti-racist declaration by teachers (Lojkine, 2005), which saw remarkable opposition to the expulsion of foreign pupils outside of France, cannot be overlooked.

In contrast, the expectations of the middle classes have not been met and their frustration reveals the extent of the social crisis, which according to Louis Chauvel (2006) stems from "network-based integration" of the middle classes and "anomic drift" from the popular classes. Louis-André Vallet (2006), on the other hand, reminds us that the phenomenon of re-distribution of individuals within the rankings of mobility does not in anyway correspond to a re-structuring of opportunity of access to different social positions according to background. The increase in social fluidity (towards greater mobility) over the last forty years is valued at $4 \%$.

In this context, teaching, as the profession that is most emblematic of job security and stability of status, is a good career choice for women but also for men. Indeed, analysis of choice of profession, from the sole viewpoint of the proximity of teaching to the female habitus, obscures women's need for social recognition - as revealed by the spectacular success of girls at school. Conversely, masculine aspirations for a way of life made possible by a career in education are also eclipsed by this approach. As one of a number of social strategies, the quest for a certain standard of living may be included among the reasons for choosing teaching, often cited with regard to "privileged employment, civil servants, always on holiday" and especially with reference to women.

References to socioculturals as civilizational purposes, (diffusion of knowledge for good society, contribution to social justice), civic purposes (contribution in caritative associations), political choices (state power against poverty, inequalities), may outline the main side of this professional choice: a humanist career resolution for women and men as well. Following the large investigation in the labor universe, teachers give a good illustration for "Working to be happy" (Christian Baudelot, Michel Gollac, 2003). But the question is about the reasons : what are the anthropological needs that profession answer through its sociological organization ? As the main hypothesis we suggest to improve the cohesion of the French teachers of all grades, from pre-school level to university, manifest in the last social movement, and which can be understood as an expression of values and educational background. Collective action, common way of life and same critical of individualization oppose dramatically this professional group to business elite (Eelke Heemskert, Meindert Fennema, 2009).

\section{What is quality of life?}

\subsection{The concept to standard of living}

When it comes to a good social quality of life, employment - in all its aspects - is the uppermost priority for French people (CSA-l'Humanité-NVO, 2007). First of all, there is of course the uncertainty related to access to employment, followed by that related to holding on to it. But all of the elements that define the conditions under which a one exercises one's occupation also come into play, as does the way of life they entail, in terms of equality of treatment between the sexes, satisfaction from the activity itself, taking pleasure in one's work and as a consequence the feeling of being happy. Use of this notion implies that the objective conditions of an occupation are observed alongside feelings of well-being or discontent. Thus, to the material criteria of "the good life" such as salary and status, must be added those belonging to the subjective balance that individuals draw from experience in their professional field. This, for example, is the case of professions that pay little in terms of wages, but are respected for their great social utility and practised by way of vocation and personal development - the figures of the nurse and fireman are good illustrations. Social legitimacy therefore strongly contributes to the positive image of the teacher. But personal fulfilment, even more than this, must be of a creative order. Indeed, quality is an art de vivre and that kind of perfection cannot be achieved by just anyone. Endorsing a certain quality of life is a distinctive and distinguished sign, marking out a social category that is doubly privileged both culturally and economically and aspires to the satisfaction of the higher needs of mastery and personal growth. In the same way that, in the past, a man of worth was a man who held power, which in turn put him in an enviable social and economic position, today the issue of quality of existence is the mark of an individual who has the means to choose. Aside from the fact that the criteria of quality living are prescribed by 
the elites (Pierre Bourdieu, 1979), it seems that in principle, the very concept of quality presupposes a set of strategic decisions with the potential to transform reality rather than simple endure it (Michel Lallement, 2003).

Thus, certain socio-professional categories are able to produce and incarnate behaviour models, social styles, and can even take the form of pressure groups on certain issues, such as cycling in the city. As a consequence, the choice of quality of life expresses an elitist type of humanism that is unique to certain privileged categories with the resources to bring about their emancipation and their development as individuals.

De Singly argues that individualism is a form of humanism: "since the Renaissance, individualism has been a society project in which everyone should seek the best conditions to realize their full potential and for their own personal fulfilment. The current modes of expression of attachment to the values of solidarity are differing paths that ultimately pursue the principles of universalism that were inaugurated by the French Revolution. Indeed, this is precisely what is shown by the different studies on the subject of young people's values (Galland, Roudet, 2001) and how they relate to commitment, or even the surveys conducted among newly qualified teachers (Rayou, Van Zanten, 2004). Although it has negative connotations and is generally understood to be the source of expansion of liberal ideology, unanimous acceptance actually hides the concrete manifestations of republican individualism, where the quest for the common good and for self-determination are not necessarily contradictory principles. Professional groups such as managerial staff therefore have the means to define this norm and generate corresponding lifestyles. Teachers occupy a prime position among them on account of their high level of learning, protected status and educational function.

\subsection{Sampling and data collection}

In order to provide evidence that expressions of connexion to teachers'community and civic opinions, we collected two types of information quantitative and qualitative including each degree in the french educational system which offer two main sectors, public (state) and private confessional (catholic). The reason for including that different professional levels, generally studied for their specificities, is that they are central among the social space of the labor market in the sense that they are active in promoting a humanistic ideal because of their humanistic occupation. Above internal diversity of this professional group, we focus on a more or less common way of life, and the link between a well fare identity and opinions for the defense of important civic values. We examine the subject of "ordinary resistance" (Michèle Dobré, 2007), what we would call "serene resistance" about a professorial attitude.

In this study (Note 1), the concept to standard of living shall be explored through the example of teachers, with the objective conditions of their lives and their place in the social hierarchy of employment taken as a starting point. Then the subjective opinions of teachers about their profession shall be drawn on in order to allow their definition of a "quality life" to be heard. Since all of the values associated with this line of work serve as indications of their humanism, we shall thus examine the hypothesis that teachers' own definition of a good quality of life may be a form of resistance to liberal models. Next, the significant feminisation of this professional body as well as the masculine approach to this choice of occupation shall lead us to test the hypothesis that beneath the deceptive appearance of the academic tradition lies a progressive profession. The lifestyles of this professional group, teachers' satisfaction or social frustration in their working and private lives, as well as their attachment to humanist values shall be examined here through statistical and qualitative portraits.

\section{Quality of life and the teacher's condition}

\subsection{Choosing security}

All too often analysed from the sole perspective of the stereotypical female occupation, choosing a career in education can primarily be a mixed response to the constraints of a difficult job market. The pursuit of job security is an advantage that cannot be overlooked for women and men alike. This is especially evident in career paths that were not destined for teaching at the outset. The importance of this aspect is especially evident in accounts of non-linear academic pathways or professional reconversions, while students with a flair for a certain subject who "naturally" embraced teaching are far less mindful of it. Of course, the appeal of teaching itself often comes to the fore, alongside an appreciation of contact and exchanges with pupils, the pleasure of learning and an aptitude for a particular discipline. The interviews (Note 2) reveal that men have not yet learned to express the idea of a pedagogical vocation, and it is only through by the strength of their involvement in unions or through the confidence acquired after many years in education that they eventually lay claim to it.

For the most part, teachers are satisfied with their occupation, they are happy in their work (92\%) and in their personal life (93\%) to the extent that given the choice of starting over they would choose this profession again $(80 \%)$ and strongly recommend it to young people $(70 \%)$. They all agree that it is "un beau métier," for in 
addition to the pleasure of working with young people and the feeling of utility is the sense of finding one's place.

- (Would you do it again?) "After 17 years working for a company I do not regret my reconversion on account of my freedom, but I miss my old salary. In terms of having time for family it's great”. ( $\mathrm{N}^{\circ} 45-\mathrm{Woman}-43-$ Teacher in state lycée - Father baker - Mother baker - Partner bank clerk - 2006 Survey).

- (Would you do it again?) "It hard to give an answer just like that. Erm...I'd liketo say yes when I think of the children and the quality of life, I'd say no when I think about my professional advancement because its a job where we know we start out as primary school teachers and we'll finish as primary school teachers and, well, that's all there is ". (N58 - Man - 54 - Married - 1 child - Teacher in state primary school - Mother housewifePartner teacher - 2006 Survey).

Overall, men are more optimistic than women. They do not feel as helpless in their occupation when faced with differences between pupils, or with families whose apparent failure to take responsibility for their children gives rise to a feeling of powerlessness that is more enhanced among women. Moreover, they are also less inclined think that the image of the public education system has suffered damage in the eyes of pupils' parents than their female colleagues. Women hold a significantly more negative view of families and their abdication of responsibility; they complain a lot about having to fill the disciplinary roles of parents who have given up.

But these observations are only applicable in virtue of uneven social profiles; it is obvious that this male optimism, tainted with tolerance, correlates to an ascendant social mobility that is much more frequent among men and as such more strongly perceived by them. The best objective situation of female teachers does not, incidentally, give rise to a sense of belonging to the category of white-collar executives nor to high valuation of income. Women liken their status to that of top-level executives half as often as men do (15\% compared to $31 \%$ ), and under-value their income. About $40 \%$ of female teachers situate their salary in the lower-middle quarter income bracket compared with only $29 \%$ of men. This curious devaluation by women is explained by their disadvantaged position in comparison with their partners, but is also relative to their family background. Most often from privileged backgrounds, women view their own trajectory as one of social decline. Whereas for $46 \%$ of men becoming a teacher has been a social climb, for $60 \%$ of women the opposite is true. But it is not purely relative, for these are women who are active in the lowest levels of education, (87\% of nursery teachers and $66 \%$ of primary teachers are women, versus the $69 \%$ of teachers in higher education who are male). And here, the growing disdain as one descends the ranks of the educational establishment from university to nursery has little to do with subjective impressions. The ladder that women must contend with is very real indeed, and governs salaries as well as esteem.

\subsection{Stability}

While over the course of the interviews stability of status clearly emerges as one of their initial motivations, it later secures for teachers the conditions for fulfilment. Thus the peace of mind acquired through employment frees them from worries, allowing them to look after themselves, as much in terms of hygiene and health as leisure activities. One young teacher even says that their occupation provides them with an ideal lifestyle. Comfort and good material living conditions are regularly cited by the teachers questioned, as it is not exactly a dangerous job, as one teacher comments, not without a hint of humour.

This social category thus enjoys good objective conditions of existence, with $75 \%$ of them living in a house, at any rate in a residential zone ( $62 \%$ of homes) which in $40 \%$ of cases is situated in the centre of town, which is an indication of the high value of real estate assets as well as an environment that is well provided for in terms of urban infrastructure. This observation concerns women in particular, who are most often home-owners (75\% compared with only $70 \%$ of men).

In addition to their stable professional status, their family life is also stable: $60 \%$ are married, with an average of 2 children, whose daily schedule is organized around regular meal times - a convivial moment during which television is strictly forbidden. Aside from the priority given to communication between those present, the quality of meals is also accorded special attention by this category; fast food and ready-meals are harshly condemned and a balanced diet promoted instead. In this regard, female teachers attach greater importance to the nutritional value of what is eaten and are considerably stricter than men about having meals at fixed times without television.

Thus the private lives of teachers offer an image of delightful serenity: stability, regularity, and all accounts relate the calm of lives whose primary luxury is time. Despite the relative modesty of their income, the fact remains that, objectively, they belong to the more privileged category of employees, both by virtue of their social background and through the position of their partners. In this survey as in others, (F. Charles and J.P. Clément, 
1997 ; L.A. Vallet and A. Degenne, 2000 ; S. Devineau and A. Léger, 2001), 23\% have a white-collar father and $28 \%$ have a white-collar partner, compared with only $17 \%$ who have blue-collar fathers and just $4 \%$ blue-collar partners. Women come from a more privileged social background than men do. Women more frequently have a white-collar or business owner father (25\% and $16 \%$ respectively compared with $22 \%$ and $16 \%$ for men). It is also among men that we find the greatest number of fathers who are labourers, non-managerial employees or in the intermediary professions $(18 \%, 13 \%$ and $24 \%$ respectively, compared with $16 \%, 10 \%$ and $21 \%$ for women). The social position of the partner or spouse broadens the gap in favour of women, who are markedly better-off than their male colleagues. So $37.5 \%$ of women have a managerial-level (cadre) partner or spouse, compared with only $30 \%$ of men, whereas $51 \%$ of men have a partner or spouse in the intermediary professions, and $16 \%$ a partner or spouse who is a non-managerial employee (compared with $34 \%$ and $10 \%$ respectively for the partners of male teachers). This enviable social situation for women is nevertheless typical of the public sector.

Overall, these social portraits, established on quantitative as well as qualitative data, bear witness to the good conditions of existence of this professional group, and especially so for women. Yet, the latter feel social frustration that is tempered by the sense of fulfilment at home which is in turn made possible by this profession. Men, on the contrary, express frank personal and professional satisfaction.

\section{Quality of life and humanist values}

\subsection{Time for culture}

Teachers often refer to personal development. Among their leisure activities, reading is most often cited. Taking pleasure in nature, a taste for walking and hiking are strongly emphasized as part of the quest for simplicity, with harsh criticism - even contempt at times - for commercial activities and theme parks. Leisure activities are also a time devoted to the family, to playing with children. It is completely out of the question for them to describe what their basic daily routine is - on the contrary, there is a firm belief in stating a general model that is desirable for everyone. Having a quality life therefore means taking the time to live, to wander, to dream, in short, escaping from the constraints of routine every now and again. It also means looking after one's family, this time with an acute sense of the social utility of the time invested here, namely in the proper education of children.

- "That's the worst thing about modern society, because you always have the impression that there's something you should be doing, you're always in...got lots of things to do and saying you don't have the time." ( $\mathrm{N}^{\circ} 51$ Man - 37 - Married - 1 child - Teacher in state lycée - Father teacher - Mother teacher - Partner events stewardess - 2006 Survey)

The answers to the open questions in the questionnaire provide a good illustration of the types of leisure activities where the nature-culture duo is a recurring feature, including for hobbies. The differently gender-marked dream holidays also reveal an ever greater desire for culture. $23 \%$ of teachers answered with "A cultural cruise in the Mediterranean" (feminine dream), behind this came "A safari in Africa" for 14\%, "A sea-crossing manning a sail-boat" 9\% (masculine dream) or "A farming holiday" $6 \%$.

Their activities over the holidays reinforce their cultural and sporting tendencies, with the addition of trips that the caption "Sport, Nature et Discovery" captures in a nutshell. As for restaurant outings, teachers' preferences are for local eateries, gastronomic cuisine and pizzerias, any restaurant except fast-food outlets, as one of them put it. Teachers are totally in tune with the environmental values of their time, and so embody them better than anyone else, no doubt because they enjoy both sufficient time and income - ingredients that are lacking to numerous other professional categories. But above all, these are determined educators, profoundly aware that theirs is a very public service.

— "I mean, even what I do when I go around the supermarket matters to my pupils and my pupils' parents. When you bump into them at Leclerc (supermarket) they come over to shake your hand and then, off we go! They will start a conversation about their child and them somewhere along the line they'll look at what's in your trolley, it's funny, but we really do have a public occupation, which, incidentally, belongs to our pupils and to their parents." (Interview N: DS500087: Woman, 28, trade union member, secondary level teacher, teacher at lycée, 2009 survey).

\subsection{A human profession}

Teachers take pleasure in their work, they like their job which, according to them, allows them to uphold values to which they are committed such as justice. Equality is, so to speak the beacon value of their approach to life, in domestic and personal spheres as well as in civic domains. Their attachment to the State's social missions that are implemented by the public services and their strong expectations of state action to combat unemployment and inequality serve to demonstrate the extent to which this professional body is rooted in a humanist philosophy. 
Teachers express a very broad refusal of globalisation (71\%), which is rejected as a threat to a decent quality of life. Their vision of society nowadays is therefore highly critical, so that $45 \%$ are quite supportive of the alternative-globalisation (alter-mondialist) movement.

Competition emerges from these interviews as a value that is not recognized in this profession, even one that they should struggle against. When it comes to the reputation of establishments, there is a strong sense of the unease in admitting the contradictory state of affairs with the principles of equality of access to education for all children without distinction. And so one is immediately reminded that in the end, each teacher is concerned with their own pupils, and applies the principle of justice among them, even if outside injustice rules. The world of education therefore proudly declares its particular gift relatively to other spheres. One teacher, cites the values that his/her job, unlike other occupations, allows him/her to uphold: "Respect and friendship".

- "Everyone has their place. We are not in competition, there is no contest. It's different from other professions where individuals always have to do better than other people. For us, each of us does our job, we teach our pupils, we just do what we have to do without competition" - $\mathrm{N}^{\circ} 46$ - Man - 46 - Teacher in public lycée Teacher father - Housewife mother - Partner sales assistant - 2006 Survey).

Teachers are content people in world of which they are harsh jusdges. Solidarity emerges as a major concern, worthy of unrelenting criticism of the progressive decline in professional status and of the deterioration of young people's conditions of entry to employment. Instability, social injustice, pollution, globalization and the trail of de-localizations that follow - all of this is worrying, sometimes even appalling. As a result, the conclusions they draw from these situations are more inclined to fatalism or, more often, pessimism and they withdraw to the only remaining space, which is their personal lives. Is this a feeling of powerlessness or rather an admission of weakness before the challenge that lies ahead? At any rate, they still have the hope of stimulating critical thinking in the classroom.

It is true that they are only moderately politicized, in that $73 \%$ of them do not belong to a trade union, and that only $50 \%$ of those asked claim to have an affinity with a political party, while $13 \%$ said they were not interested in politics and $29 \%$ said they had no preference between the parties. In our sample, one teacher out of 1576 held an elected post, to which he devoted all of his spare time, and one young man of 26 mentioned his commitments on the local council. Nevertheless, there is an educative presence in the local area that extends well beyond the classroom through voluntary contributions to cultural, sporting, political or charitable activities.

As such, teaching appears to provide a good way of living according to the values that they uphold.

\subsection{The equality of gender roles}

Over the course of these surveys, the portrait that emerges is one of a peaceful universe where both men and women play an important role in the home and above all with children. The sharing of domestic tasks, although not completely free of gendered stereotypes, does show a good level of fairness. Among teachers, equality of the sexes is not merely paid lip service in the name of the fundamental principles that the profession ought to put into practice - it actually corresponds to a way of life as well.

In the same way, it seems that their egalitarian values converge in the feminist cause, which alone offers any real possibility for their expression. One notes that by withdrawing into their personal spheres - a act that is as pessimistic as it is fatalistic in the face of the social misery around them - there is a sense that their basic principles cannot be developed outside of there private lives, and only to a far lesser degree in their social function with children or through civic commitments in the city.

— "Well, one of the major equalities is equality of treatment between men and women! Our salaries are strictly equal. This is practically one of the only jobs in the civil service where there is no difference, in principle; among teachers, people are all treated the same way. It is possible that in other sectors of the civil service it's not quite the same, as regards promotion, things like that. I don't really know, I mean, maybe I'm getting ahead of myself." - ( $\mathrm{N}^{\circ} 27$ - Man - 52 - Divorced - 1 child - Teacher at lycée - Father mechanic - Mother no occupation. 2006 Survey).

— "I try to do as much as I can while I'm at work so that I have as little as possible to do at home, so that I can do other things. Like, well, being around for the kids, loads of things, cooking, doing sport like weights, it's a job that allows for quite..." - ํ3 - Man - 51 - Married - 4 children - Teacher at state secondary school (collège) Father gendarme - Mother housewife - 2006 Survey).

— "Especially as over there, at the transfusion centre, I used to work at night, I'd work weekends, I worked on Christmas Day. So when you have young children with whom you'd like to celebrate Christmas, it's not great...And my husband was, or rather is, a teacher, so we decided, well, that if I could change track that could 
be pretty good". - N¹3 - Woman - 40 - Married - 2 children - Teacher in state primary school - Father bank employee - Mother housewife - Partner teacher - 2006 Survey).

— "Yes because I have a child, when he was young, when I got back from work I would spend hours playing with him and that's really positive. It's really good for the education of your child to have the possibility to be around him. You have to do it and it is really important to separate personal time from work time." - (N58 Man - 53 - Divorced - 1 child - Teacher in lycée - Father painter - Housewife Mother - Partner teacher - 2006 Survey).

— "Yes! I have what I need! A family, a house - I don't sleep outside and I'm doing what I enjoy...It's not a luxurious existence - and I think I wouldn't have liked it anyway! But I have sufficient resources to live a normal life in the sense that me and my family understand it. We do quite a lot of sport in addition to being by the sea, which means I can go sailing with my kids...everything's OK!'. - N²8 - Man - 45 - Married - 3 children Teacher in a public primary school - Father labourer - Mother housewife - Partner schoolteacher - 2006 Survey).

_-'In terms of male-female equality, completely. It's not an area where we are up against male chauvinism! What's important is that we don't get tainted by economic interests, as is the case in other fields. There are no competitors so there are no dirty tricks. " - $\mathrm{N}^{\circ} 61$ - Woman - 55 - Married - 2 children - Primary schoolteacher and head instructor for trainee teachers at public primary school - Father industrialist - Mother secretary Partner farmer - 2006 Survey).

— "I dream of a world in peace with no wars of religion. I hope that there will not be a pandemic of any kind of disease. As a priority I hope that my children live to be happy and lead fulfilling lives."- N57 - Woman - $52-$ Married - 2 children - Teacher at public lycée - Father shopkeeper - Mother shopkeeper - Partner teacher - 2006 Survey).

\section{Teachers and Humanism}

The question of popular classes' rights to academic success seems to have been abandoned somewhat under the effect of widespread defeatism: teachers feel powerless in the face of the amplitude of the problems and plead general responsibility. There are, however, a number of exceptions such as the central role of the Sate against privatisations, the reminder of universalist principles for secularism or the legacy of scientific reasoning as opposed to beliefs (Devineau \& Annoot, Bussi, Léger, 2006). For example, at the heart of this highly educated and highly qualified category, one finds the public-private and republican-liberal cleavage, which against all expectations, actually cuts through the male-female divide. Indeed, analysis of a whole cluster of indicators shows two social universes, whose structure is founded on their distance from (or proximity to) liberalism, reflecting the composite nature of this profession, if only by the different levels of teaching or by its two sectors, public and private (see chart). There is nothing surprising about finding members belonging to more working class social spheres or, on the contrary, more privileged backgrounds among teachers - this is typical of the middle classes. One thus comes upon the universe of managerial-level executives who seem to offer far greater support for changes to the conventions enshrined in labour law or in the economic order between privatisations and nationalisations or categories of teachers who may also be open to para-sciences, managerial and personalist ideologies (D. Boy, G. Michelat, 1986 ; D. Hervieu-Léger, 1987 ; J.P. Le Goff, 1990).

All in all then, if we go back to the analyses of Alain Chenu and Nicolas Herpin (2006), we cannot make conclusions on behalf of this professional category, which has shown strong, compact or homogeneous resistance to the restructuring of the order of civic priorities between equality and freedom. However, the humanism of the majority of teachers is based on equality of the sexes, security and respect in their work, modest material needs and the importance of time for themselves and their families. This category has found that teaching offers the conditions in which they may uphold values founded on human rights. 
Chart: Factorial analysis of correspondence between the opinions of 1576 teachers from nursery through to university in the public (state) and private (catholic) sectors ( IRSHS Rouen 2006 Survey).

Factorial Analysis of Correspondances: actives variables : items 1 to 9.9 and items 13.1 to $14.14: 235$ forms. Axe 1 and Axe 2 .

\author{
Private sector \\ prefer to deal with private sector \\ public services do not offer \\ a better guarantee of the \\ State's social missions than \\ the private sector \\ not a member of any political party \\ father farmer \\ mother farmer \\ -Women \\ primary level teacher \\ house in the country \\ two children
}

\author{
lecturer \\ university \\ single \\ Men appartment \\ city centre \\ member of a political party \\ the 35 hour week is \\ a step forward \\ in favour of \\ alter-mondialism \\ the State can reduce \\ inequalities \\ confidentiality and \\ user satisfaction \\ better guaranteed \\ by the public sector \\ prefers to deal with public sector \\ Public sector
}

\section{Conclusion}

Although for the majority it is a feminine occupation, choosing teaching may also be understood today as a mixed response to the constraints of a difficult job market. Also, at a time when men also seek personal fulfilment through their children and home, and when, on the contrary, women are devoting more of themselves to their work, the question of equal partition between the sexes is resolved in fairly exemplary fashion in this profession. In short, women and men each commit to this choice of profession, in their own way, according to their gender, as being the best way of putting their progressive ideals into practice.

The objective conditions for employment in teaching correspond to certain feminine aspirations connected to the daily organisation of budget-time. But this is not totally satisfying for women from privileged backgrounds, with qualifications, who consider the choice of teaching to be a second-choice, guaranteeing equality of treatment in their career, while respecting their role as mother.

However, restricting oneself to only those aspects most often put forward on the subject of women is very reductive because in practice, the teaching professions also draw on an a whole set of ideological constructs. Criticism of globalisation and of the liberal order is worthy of the carefully thought out choice of a certain lifestyle, one that is especially pronounced among men. And so it is with the attachment to values of social equality, to public services, the commitment to voluntary work, the positive appreciation of the alter-globalisation movement and affirmation of the central role of the State.

It becomes clear that teachers at all levels, from nursery through to university, in the public or private sector, male or female, define a good quality of life as a form of resistance to a liberal model that is seen as destructive of human principles. Thus, in France, teachers are not the last to oppose the dismissal of the universalist heritage of the post-war Republican model. As a privileged category at the heart of the middle classes, they have the means for cultural distinction, and they use them to uphold human rights, with sexual equality coming to the fore of a meritocratic philosophy. 


\section{Box}

Our database is made up of the findings of a total of six surveys, including one main survey by questionnaire in 2006 conducted among 1576 teachers, active at various levels of the French education system, supplemented by a qualitative investigation of some 63 interviews in 2007. Our study is based on a series of resource indicators, notably real estate assets and social origin, indicators of self-realization in coupledom and number of children, leisure activities, political indicators of attachment to economic principles and to certain economic values. In addition, constructing satisfaction indices has allowed us to evaluate the feeling of happiness in working and personal life. Finally, the exploration of quality of life from the point of view of teachers is supported by analysis of the interviews.

Before this main study, we explored the French teachers universe along ten years, through temporary immersions inside different schools, and 6 quantitative experimental surveys, (2000-2004, University of Caen), and (2005, University of Rouen).

After this main study, there is an ongoing survey whith 9 interviews with educational officials and trade union (FSU : the most important trade union in education sector) from primary and secondary education, and 6 interviews with educational managers in political programs (2009-2010, CMH-MRSH, University of Caen,).

\section{References}

Baudelot C., Gollac M. (2003). Travailler pour être heureux? Le bonheur et le travail en France, Paris, Fayard.

Bourdieu P. (1979). La Distinction, critique sociale du jugement, Paris, éditions de minuit.

Boy D., Michelat G. (1986). "Croyances aux parasciences : dimensions sociales et culturelles”, Revue Française de Sociologie, XXVII.

Chauvel L. (2006). "La déstabilisation du système des positions sociales, L'épreuve des inégalités (Lagrange H. dir.), Paris, PUF, 90-112.

Chenu A., Herpin N. (2006). "Le libéralisme économique gagne les pays nordiques, la France résiste”, L'épreuve des inégalités (Lagrange H. dir.), Paris, PUF, 41-66.

De Singly F. (2005). L'individualisme est un humanisme, essai, éditions de l'Aube, la Tour d'Aigues.

De Singly F. Corcuff P. Ion J. (2005). Politiques de l'individualisme, coll. La Discorde, Paris,éditions Textuel.

Devineau S. (2007). « Le choix d'enseigner : l'affirmation de valeurs sociales », Empan, N65, Société d'éditions Recherches et Synthèses, ERES, Toulouse, (87-91) Avril.

Devineau S. (2008). «Education et Altérité : l'humanisme des enseignants », in Lutter contre les discriminations : la gestion de la diversité, une solution envisageable ?, Caritas-Luxembourg-PROGRESS.

Devineau S. (2009). Les enseignants et les parents d'élèves, in Sociologie des groupes professionnels, D. Demazière, C. Gadéa (dir.), La Découverte, 332-341

Devineau S. (dir.), Annoot E., Bussi M., Léger A. (2006). Sociologie des enseignants : étude en Haute et Basse Normandie, Rapport de recherche, IRSHS, GRIS-CMH-CIRTAI-IDEE.

Devineau S., Léger A. (2002). Les enseignants et leur famille, Conditions et genres de vie (dir. D. Le Gall et S. Juan), France, L'Harmattan, 99-121.

Devineau Sophie. (2006). "L’école pour les femmes : rapports sexués aux savoirs professionnels chez les candidats à l'IUFM", in L'Orientation Scolaire et Professionnelle, mars.

Devineau, S. (2005). «Norme scolaire et valeurs féminines : le cas des candidats à l'IUFM », Trames, Educations féminines, $\mathrm{n}^{\circ} 12$ Avril, 131-140.

Dobré M. (2007). «Consumption: A Field for Resistance and Moral Containment», in Zaccaï Edwin Ed.,, Sustainable Consumption, Ecology and Fair Trade, Routledge, London, p. 163-177.

Forsé M.,Parodi M. (2005). The priority of justice. Elements for a sociology of moral choices, Bern, Peter Lang. Galland O., Roudet B., (dir.). (2001). Les valeurs des jeunes, Paris, L’Harmattan, collection Débats-jeunesse.

Heemskert E., Fennema M. (2009). "Network Dynamics of the Dutch Business Elite", in Journal of the International Sociology, Vol. 24, ํㅜ, Novembre 2009, pp. 807-832.

Hervieu-Léger D. (1987). «Vers un christianisme des communautés émotionnelles », L'état des religions, Paris, éd. La Découverte.

Lallement M. (2007). Le travail : une sociologie contemporaine, coll. Folios essais, Paris, éditions Gallimard. 
Lallement M. (2003). Temps, travail et modes de vie, Coll. Sciences socials et sociétés, Paris, PUF.

Le Goff J.P. (1990). Le mythe de l'entreprise, Paris, éd. La Découverte.

Linhart D. (2009). Travailler sans les autres ?,coll. Non Conforme, Paris, éditions du Seuil.

Linhart D., Mauchamp N. (2009). Le travail, coll. Idées reçues, Paris, éditions Le Cavalier Bleu.

Lojkine J. (2005). L'adieu à la classe moyenne, Paris, La Dispute.

Mauger G. (2005). L'émeute de novembre 2005. Une révolte protopolitique, Broissieux, éd. Du Croquant.

Mauger G. (2007). “Ce que veulent les jeunes”, Humanité Dimanche, 22-27 Février.

Pezé M. (2008). Ils ne mouraient pas tous, mais tous étaient frappés, Paris, Pearson.

Préteceille E. (2006). La ségrégation contre la cohésion sociale: la métropole parisienne, L'épreuve des inégalités (Lagrange H. dir.), Paris, PUF, 193-246.

Rayou P., Van Zanten A. (2004). Enquête sur les nouveaux enseignants. Changeront-ils l'école ?, Paris, Bayard.

Thélot C. (1994). L’origine sociale des enseignants, in DEP. $N^{\circ}$ spécial Connaissance des enseignants, Éducation et Formations, 37 mars.

Vallet L.A. (2006). "Une société plus ouverte: la France entre 1970 et 1993”, L'épreuve des inégalités (Lagrange H. dir.), Paris, PUF, 113-152.

Vallet L.A., Degenne A. (2000). L'origine sociale des enseignants par sexe et niveau d'enseignement, Évolution entre 1964 et 1997, in DEP. Éducation et Formations, 56, Avril-Juin, 33-40.

\section{Notes}

Note 1. Source: survey of 1576 teachers of all grades from pre-school level to university, carried in Haute and Basse Normandie. Sample stratified, by gender: 54\% female, 48\% male; teaching grade: pre-school $16.7 \%$; primary school $20.1 \%$, secondary school $20 \%$; high school $23.1 \%$. Degrees wheighted: 1 rst degree $36.8 \% ; 2^{\text {nd }}$ degree $43.1 \%$; high school (3 last years of secondary education) $23,1 \%$, higher education 18,6\%. Average age: 42. Sectors: state $65 \%$; private $34 \%$.

Devineau S. (ed.), Annoot E., Bussi M., Léger A., (2006) Research Report, GRIS Publication Series, IRSHS, Université of Rouen, Upper Normandy ; Constant J., (2007), Statistical Series Report, CMH-Dyreso, Publication Series, MRSH, University of Caen, Lower Normandy; Vernier M. (2008), Statistical Report, CMH-Dyreso, Publication Series, MRSH, Lower Normandy.

Note 2. Source: Follow-up research : 63 interviews with teachers; teaching grade: pre-school, primary school, secondary school, high school, Devineau S. (2007), GRIS Publication Series, Université of Rouen, Upper Normandy - 6 quantitative experimental surveys, University of Caen (2000-2004), and University of Rouen (2005) - Ongoing survey, MRSH, University of Caen, (2009): 9 interviews with educational officials and trade union (FSU : the most important trade union in education sector) from primary and secondary education, and 6 interviews with educational managers in political programs.

\section{Information}

CSA-L'Humanié-NVO, (2007), Priorité des électeurs, 28 février.

IFOP-Le Monde de l'Education. (2007), “Le vote du monde enseignant”, Janvier.

IFOP-AFD. (2006), “Les français et l'aide au développement”, 78839, Juillet

IPSOS. (2006), "La sociologie du vote au referundum : le Non des classes actives, des classes populaires et moyennes et de gauche", Les sondages en tant qu'outil d'analyse électorale : l'exemple du referundum sur le projet de la constitution européenne, 30 Mai, IPSOS.fr. 